\title{
A COMPARISON OF FIREFIGHTING HIGHER EDUCATION CURRICULUMS BETWEEN CHINA AND THE UNITED STATES
}

\author{
Yunbo Zhang \\ China People's Police University, China \\ Ray Hsienho Chang ${ }^{1}$ \\ Embry-Riddle Aeronautical University-Worldwide, USA \\ Dengyou Xia \\ China People's Police University, China
}

\begin{abstract}
This research aims to systematically compare the educational concepts between the U.S. and China, to answer a research question: what courses, based on the experience of developing fire services in both countries, should be included in firefighting higher education programs to increase knowledge, skills, and abilities (KSAs)? The authors utilized the method of content analysis and applied the theoretical framework from emergency management to compare those curriculums from both countries into common contextual research criteria. Results of our analysis demonstrate that the two countries have similar expectations by which to develop core KSAs in their firefighting higher education programs.
\end{abstract}

Keywords: Firefighting Higher Education, Comparison Research, US Fire Education, Chinese Fire Education, Content Analysis

\section{Objectives}

Every profession, either of great complexity or simplicity, relies on certain skills that account for its worth or merit. As the profession's complexity increases, the expected level of competence goes up. Lindell et al. (2006) believe that educational programs collect relevant principles and procedures from different disciplines, and thus develop into an organized body of knowledge, which can be applied to solving problems. Those problem-solving capabilities are called knowledge, skills, and abilities (KSAs) that practitioners acquire through education

1 Correspondence: Changr2@erau.edu 
and training (Blanchard, 2004; Freidson, 2001). One of the major KSAs in the profession of emergency management, more specifically, is to teach students how to improvise solutions and solve novel problems that they did not anticipate in planning or experience in training (Drabek, 2003; Kreps, 1991; Lindell et al., 2006; Broman, 2008). This ability is developed during a fire student's higher education (O’Neal, 1998).

The United States (U.S.) and China both experience various types of natural disasters, and thus each has established a national emergency management system, as well as programs to educate their disaster responders. To provide a consistent firefighting education, educators in the U. S. established a national standard curriculum model for the fire service higher education, known as the Fire and Emergency Services Higher Education (FESHE) Model (O'Neal, 1997). China is also one of the countries confronting all kinds of disasters. Over the years, it has developed a comprehensive domestic emergency management system and a set of contingency plans to respond to a range of disasters and emergencies. (Yi et al., 2011; Wang et al., 2016). As the Chinese government develops its fire services, firefighting education expands, which includes both undergraduate and graduate level programs.

Since the two countries have firefighting higher education programs and also established nation-wide standards and curriculums, the present research explores what courses, based on the experience of developing fire services in both countries, should be included in firefighting higher education programs to increase KSAs? To answer this question, the researchers first review the curriculums of American and Chinese firefighting higher education programs, compare the courses taught in each country, and then identify the common courses and ideas shared by both countries. By using systematic comparison, we are also able to identify the differences between the two countries and consequently discuss the possible reasons and rationales for teaching different courses in China and the U.S. At the end of this paper, we provide recommendations to the Chinese firefighting training institutes, to assist them in providing a broader, wider, and a more emergency management-centered educational approach. Due to the newly established Ministry of Emergency Management (MEM), which regulates the fire services in China, this paper provides original insights and strategies to better bridge the firefighting and emergency management educational programs.

\section{Perspectives}

\section{The Importance of Higher Education for Fire Service}

The fire service higher education is not a new topic in the U.S. Researchers believe that as the fire service has evolved into a profession from an occupation, it now demands more complexity in KSAs acquired through academic and formal training settings (Leath, 2007). It is commonly believed that training, education and experience are three of the most important factors for fire service personnel, as discussed earlier in this paper, among which education is the basis for future training and experience (Lindell et al., 2006).

A wealth of literature exists on the importance of college education for fire personnel. Latin (1992) and Richmond (1998), for instance, believe fire chiefs must complete college educations (bachelor's degree or higher) to serve on the rapidly evolving fire service profession. Based on Bockenstedt (1997) and Witt's (1996) analyses, receiving a college education benefits firefighters as they are more qualified to finish job tasks and fulfill promotional requirements.

\section{The Problems Existing in United States' Firefighting Higher Education}

As more scholars and practitioners focus on the importance of firefighting higher 
education, some also discuss the limitations and possible improvements of current higher education programs. One limitation is the knowledge imparted to the student mainly derives from experience, rather than empirical research that is conducted in academic settings, the fire service education is centered on experiential or consensus knowledge (Leath, 2007; Mourchid, 2006). Consequently, in order to teach fire students from instructors' professional experience, the line between firefighting training and education is blurred (Snodgrass, 2011; Leath, 2007; Mourchid, 2006).

Although real world experience is valuable to become a qualified firefighter, establishing standards for education and training is critical to improve the professionalism in the field (Alexander, 2003; Clark, 1993; Snodgrass, 2011). Thus, the U.S. National Fire Academy published a standardized curriculum to avoid common duplications in the training and education, such as unnecessary courses and training certifications for fire service personnel.

\section{The Standardization of Higher Education in the United States}

FESHE was established by the National Fire Academy (NFA) in 1999. It is composed of volunteers from the fire service and academia. It has established a national standard for fire-related education by providing a fire-related standardized curriculum for both undergraduate and associate degrees, which details the major components of the education.

Beginning in 2000, the Fire and Emergency Services Higher Education Conference has convened every year in Emmitsburg, Maryland, to discuss educational issues with the nation's fire personnel. Most scholars and practitioners believe the FESHE Model is successful for the American fire higher education. The curriculum is generated, updated and empowered by a group of committees that consist of academic and college educated fire and emergency service leaders, based on their years of on-the-job experience and the identification of the practical needs in the business. The curriculum is designed to make education meet these practical needs. It is also called a "peer-driven" model by some scholars and in some official documents published by the U.S. Fire Administration (Snodgrass, 2011; Angle et al., 2013; U.S. Fire Adminisration, 2019a).

\section{The Fire Higher Education in China}

In the Chinese academic world, few words are written on this topic, though China started its fire service higher education program over four decades ago. The reason behind this is the educational system in the fire service is somewhat exclusive to other researchers in the field. Unlike in the U.S., whose fire service is provided by career firefighters and volunteers, China utilizes a para-military system called the Public Security Fire Force, to provide public fire service and domestic disaster response. In China, there are two academic institutes that provide the firefighting higher education. The first is the Chinese People's Armed Police Force Academy (CPAPFA), which provides a baccalaureate and postgraduate education. The second is the Public Security Firefighting Higher Education School, which provides an associate level education. Both institutes rely on a peer-driven approach to make sure their education is appropriate to the fire service practice. These peers include firefighters, scholars from different disciplines, and governmental officials. Comparing to the U.S. peerdriven approach, they do this by updating the curriculum regularly, just as the FESHE conference does, but not as frequently. FESHE updates the curriculum each year, while CPAPFA does this every five years. 


\section{Comparative Research Related to Disaster and Emergency Management}

Comparative methodology is defined as "a method of analysis that focuses on several objects of study in order to identify similarities and differences" (Goedegebuure \& Van Vught, 1996; Paisey \& Paisey, 2010). This type of research is comparing and contrasting variables to identify the reason why change occurs, the causes that make for a successful government, and how policy can be made effectively (McEntire \& Mathis, 2007). In other words, comparison helps us to understand, explain, interpret, and verify or falsify generalizations (Sartori, 1991). Furthermore, comparison facilitates "thick description" (Geertz, 1973) and limits "conceptual stretching" (Sartori, 1991). Summarizing these points, Collier (1991) states:

Comparison sharpens our powers of description and can be an invaluable stimulus to concept formation. It provides criteria for testing hypotheses and contributes to the inductive discovery of new hypotheses and to theory building. (p.7)

Some researchers have already noticed the importance of understanding emergency management from a comparative perspective. They believe that as a global issue, a crosscultural view of disaster research would expand our knowledge of it and the comparative method would help us better comprehend the disasters (McEntire,1997; Peacock, 1997; Dynes 1988). They also ascribe cross-national comparison as the opportunity to learn from the mistakes and success of others to improve the practice of their own emergency (Dynes, 1988; Sinha, 1992; McEntire \& Mathis, 2007).

\section{Comparative research in fire/emergency management higher education}

Comparative perspectives are important for higher education too. Such perspectives help to deconstruct the conservative national perspective of causal reasoning, broaden the horizon for potential reforms, and improve our understanding of the internationality of higher education (Teichler, 2014). In this area, curriculum is a popular research subject for cross-system comparative studies (Ary, et al., 2010). The reason is that curriculum represents the lessons and academic content taught in schools, or in a specific course or program (Glossary of Education Reform, 2015). It plays a vital role in educational practice, provides the crucial link between standards and accountability measures, and determines the content of the subjects being taught in certain programs (National Research Council, 2004). Curriculum studies' perspective varies a lot: it could be an analysis of the goals and standards of a curriculum (An et al., 2013; Gosztonyi, 2015), teacher guides or textbooks (Ponte \& Marques, 2007; Bofah \& Hannula, 2011), or the curriculum enactment in education practice (Clarke \& Xu, 2009). The focus of these research projects also varies from educational attainment, such as problem solving, to specific aspects of education such as assessment methods (Andrews et al., 2015; Brown, 2009).

In the present research, we find two comparative studies related to fire and emergency management higher education (Chang, 2007; Moschella, 2004). These authors realized the importance of comparative research in this subject years ago and tried to introduce other countries' higher education to America by making a comparison in the EMS field and fire service education. However, the previous research was based on simply comparing the curriculums and course names, but not a systematic research method that follows established theories and rigorous coding processes. Consequently, the present research will analyze the contents of firefighting curriculums from China and the U.S. to better grasp the insights of developing and designing firefighting higher educational programs. More details on our 
analyses are discussed in the following section.

\section{Method}

This research aims to compare firefighting higher educations in the U.S. and China. A systematic comparison is based on explicit rules on what and how to compare. The main prerequisite for applying a comparative method is to find the criteria which permits a systematic comparison (Jahn, 2010), and to eliminate possible bias of this research such as parochialism, misclassification, degreeism, conceptual stretching and incommensurability (Sartori, 1991).

We begin our analyses by selecting samples. We utilize purposive sampling methods (Etikan et al., 2016; Palys, 2008; Collier, 1992) to select the typical cases that represent firefighting higher education in the U.S. and China. We then put the samples from the two countries into the same context by open coding and categorizing the data, during which we also categorize the code into several groups, which is also a comparison level in a latter paragraph. Then we compare the data by different levels to find the similarities and differences between these two samples: individuals (i.e., codes/KSAs) and groups (Jahn, 2010; Teichler, 2014; Landman, 2003). At the individual level, we find the overlapping of two curriculums and differences between them. At the group level, we use phases derived from classic emergency management theory to find out if the two sample curriculums show a similar pattern (Baird, 2010; Lindell et al., 2006) and a core course defined in every curriculum, as two other comparative criterion to find out if two countries have a different approach to firefighting higher education (Ary et al., 2010; Van de Vijver \& Leung, 1997; National Research Council, 2004).

\section{Table 1.}

\begin{tabular}{lll}
\multicolumn{2}{c}{ Courses in FESHE Model (National Fire Academy, 2019a and 2019b) } & \\
\hline NO. & Course Name & Type \\
\hline 1 & Political and Legal Foundations for Fire Protection (CO258) & Core \\
2 & Applications of Fire Research (CO260) & Core \\
3 & Fire Prevention Organization and Management (Co264) & Core \\
4 & Personnel Management for the Fire Service (CO266) & Core \\
5 & Fire and Emergency Services Administration (CO271) & Core \\
6 & Community Risk Reduction for the Fire and Emergency Services (C0287) & Core \\
7 & Fire Dynamics (Co257) & Non-core \\
8 & Fire Related Human Behavior (CO263) & Non-core \\
9 & Analytical Approaches to Public Fire Protection (C0265) & Non-core \\
10 & Managerial Issues in Hazardous Materials (Co274) & Non-core \\
11 & Fire Investigation and Analysis (Co285) & Non-core \\
12 & Fire Protection Structures and Systems Design (C0295) & Non-core \\
13 & Disaster Planning and Control (CO296) & Non-core \\
14 & Fire Service Ethics (Co303) & Core \\
\hline
\end{tabular}

\section{Data Sources: FESHE Model and CPAPFA Curriculum}

We select samples by using a purposive sampling method (Etikan et al., 2016; Palys, 2008). More specifically, we use typical case sampling methods to find cases that can represent both Chinese and American fire service higher education programs. By using the typical case sampling method, as Patton (2002, p.236) suggests, we work with key informants to identify what curriculums and document are typical. In the current research, the researchers previously worked in both American and Chinese firefighting higher education 
institutes, our experience enables us to identify the typical curriculums we analyze in this research. Thus, the National Fire Academy (NFA) FESHE Model curriculum and the CPAPFA's curriculum for Firefighting Command Baccalaureate Program are analyzed as the sample to represent each country's fire service higher education at the baccalaureate level.

\section{Sample Curriculum in the United States}

The NFA is a federal institute that provides training for fire service personnel, which is federally funded and part of the United States Fire Administration (USFA). NFA is organizationally a component of the Federal Emergency Management Agency (FEMA), which is part of the Department of Homeland Security (DHS). The FESHE Model is "produced, through consensus, a standardized undergraduate curriculum that is national in scope, content and outcomes" (U.S. Fire Administration, 2019b). All the courses share common titles, catalog descriptions, outlines, and content, which provide a national core of knowledge and competencies as suggested by FESHE. The model was developed collectively with fire and emergency services instructors (Angle et al., 2013). According to the FESHE Model 2019 (see Table 1 below), there are 14 courses for Fire and Emergency Services Higher Education, split into two sections: core and non-core, among which six are core courses and eight are non-core courses.

\section{Sample curriculum in China}

CPAPFA, established in 1981 and funded by the Chinese government, is the only institute certified to provide a baccalaureate education for fire fighters in China. CPAPFA started its associate degree education named Firefighting Command in the 1980s, which was the first higher education program that majored in firefighting. In 2003, it was certified to provide a baccalaureate education in the Department of Firefighting Command - named, Firefighting Command - and the program was one of the first baccalaureate programs in CPAPFA. This academy now runs six undergraduate programs and six graduate programs related to fire and emergency response. The undergraduate programs are Fire Command, Disaster Response Command and Technology, Fire Protection, NBC Fire Control, Fire Safety Engineering, Fire Investigation and Electronic Information Engineering. The authors choose the curriculum of the Fire Command program as the sample to represent the higher education for the fire service in China, since it was the first and only baccalaureate program related to fire and emergency management. All graduates from this program will work in fire services and many of them will be promoted to officers. Table 2 is the curriculum of this program.

\section{The Unit of Analysis: Skills, Knowledge, and Abilities Gained in Each Course}

A curriculum is composed of courses, but a different country might use its own language to name different courses and the name of a specific course would clearly not give the whole picture of the content of the course. Thus, the authors choose the KSAs that students could receive after taking a course, which reflects the purpose or the goal of the course, as the unit of analysis to show the similarities and the differences in fire service higher education between the two countries. The authors then generate codes to analyze the sample curriculums. 
Table 2.

Curriculum of Fire Commanding Baccalaureate program in CPAPFA

\begin{tabular}{lll}
\hline NO. & Course Name & Type \\
\hline 1 & Firefighting Tactics & Core \\
2 & Firefighting Command & Core \\
3 & Work Related Issues in Fire Agencies' Headquarters & Core \\
4 & Firefighting Equipment & Core \\
5 & Firefighting Communication & Core \\
6 & Fire Protection Structures and Systems in Constructions & Core \\
7 & Fire Agency Administration & Non-core \\
8 & Fire Hazards Monitory Administration and Management & Non-core \\
9 & Fire Dynamics & Non-core \\
10 & Chemical Security Technologies & Non-core \\
11 & Disaster Response and Rescue Operations & Non-core \\
12 & Fire Investigation & Non-core \\
13 & Fire Protection Structures and Systems in Constructions & Non-core \\
14 & Fire Protection Engineering & Non-core \\
15 & Firefighting Map-making & Non-core \\
16 & Military Service Ethics and Laws & Non-core \\
17 & Theory of Firefighting Skills Drilling & Non-core \\
18 & Fire Scene Ventilation & Non-core \\
19 & Fire Sense Water Supply & Non-core \\
\hline
\end{tabular}

CPAFA, 2016 Professional Cultivation Plan in Chinese People's Armed Police Force Academy

(Unpublished document), 2016

\section{Coding procedures}

Before the researchers coded the transcriptions, they discussed the general themes and possible codes to analyze these data. One researcher suggested using firefighting, fire prevention, and administration as three major themes to lump all codes, but soon discovered these three themes are too narrow to cover all courses in both countries. Consequently, since firefighting is part of emergency management, the other researcher suggested utilizing the four phases of emergency management (Baird, 2010; Lindell et al., 2006; Marcino \& Gordon, 2018) to categorize these curriculums. Since emergency management is established and has developed for several years, and many researchers have already carefully defined each phase and terminologies within EM, using the four phases of EM enables the researchers to clearly separate the concepts of each code, and thus better capture those insights behind the coding processes. The codes generated from the four phases of EM, or the theory-driven codes, became the first codebook used in this research. The first researcher then utilized computerbased data analysis software, Atlas. Ti, to code all transcriptions. He also developed specific emerging codes during the coding processes. These emerging codes, or the data-driven codes, are integrated with the previous theory-driven codes to create a new codebook. The second researcher then utilized the updated codebook to code all curriculums to find the differences or disagreements between the two researchers. The researchers met every week to discuss the differences between their coding results, develop new codes, or merge old codes if necessary. By analyzing the outline of each course in the sample curriculums, the authors find 
18 codes in total which could cover all subjects in the two sample curriculums (see Appendix).

\section{Research Limitations}

Content analysis is limited to the materials the researcher possesses, so is this research. The basic comparison samples chose in this paper are the curriculums for baccalaureate programs in the U.S. and China between 2017-2018. The current analysis hypothesizes that both countries deliver these courses in the same manner, and consequently some variables are not considered or compared in this research, such as instructors' abilities, credit hours, methods of instruction, and the composition of each institution.

\section{Results and Findings}

By using the methodology of content analysis, the authors assign the different curriculums written in two different languages into a general context to make the sets of courses comparable. In total, we found 18 KSAs reflected in both curriculums. The hypothesis of this research is that: If a code could be found in the other curriculum, then we may consider that both education systems hold the same idea on cultivating a certain kind of skill or ability, which could also be the reflection of similar educational expectations for the student through a certain course(s), and vice-versa.

\section{Similarities reflected in two curriculums}

After we completed the open coding processes (Field \& Morse,1985; Vaismoradi et al., 2013; Downe-Wamboldt, 1992), the authors find two sets of courses are highly similar to each other.

The Content of Higher Education for Fire Service in China and the U.S. is Highly Similar to Each Other.

Comparing the codes in both China and the U.S., there are some similarities in both curriculums (See Table 3): 1) the abilities to complete a research project, 2) fundamental KSAs to serve on the fire services, and 3) incorporating Emergency Management into both curriculums.

First of all, FESHE has a class related to the "fire research ability" and the CPAPFA, although does not provide research courses, it requires students to defend a thesis proposal and finish a research project. Consequently, although no class aims to build the research abilities in China, however, Chinese students are expected to initiate and complete research projects. As a result, the expectations of having abilities to complete independent studies are similar in the firefighting higher education of both nations.

Moreover, both curriculums expect students to have certain core KSAs, in order to serve on the fire services. These core KSAs are: 1) understanding the methods to extinguish fire, 2) understanding the methods to respond to HAZMAT accidents, 3) becoming familiar with laws, regulations, and relevant ethical issues, and 4) fire service leadership and management.

Last but not least, both institutes, although they are under different types of governmental systems, have emergency management related courses. This reflects the fact that firefighters in both countries have to shoulder the responsibilities of managing various types of disasters in their jurisdictions. We will further discuss this emphasis on emergency management related courses in the next section. 
Table 3.

Code Existence in Two Curriculums

\begin{tabular}{|c|c|c|c|c|}
\hline \multirow[b]{2}{*}{ No. } & \multirow[b]{2}{*}{ Competencies (Codes) } & \multicolumn{2}{|c|}{ Existence in each curriculum } & \multirow[b]{2}{*}{ Remark } \\
\hline & & FESHE Model & CPAPFA & \\
\hline 1 & Command & Yes & Yes & \\
\hline 2 & Disaster Response & Yes & Yes & \\
\hline 3 & Firefighting Operations & Yes & Yes & \\
\hline 4 & Hazardous material incident response & Yes & Yes & \\
\hline 5 & Emergency planning & Yes & Yes & \\
\hline 6 & Recovery & Yes & Yes & \\
\hline 7 & Hazardous material incident preparedness & Yes & Yes & \\
\hline 8 & Risk reduction & Yes & Yes & \\
\hline 9 & Fire investigation & Yes & Yes & \\
\hline 10 & Structural fire protection systems & Yes & Yes & \\
\hline 11 & Fire-related theories & Yes & Yes & \\
\hline 12 & Law-related issues in fire service & Yes & Yes & \\
\hline 13 & Ethical issues in fire service & Yes & Yes & \\
\hline 14 & Management & Yes & Yes & \\
\hline 15 & Training & Yes & Yes & \\
\hline 16 & Research ability & Yes & $\mathrm{N} / \mathrm{A}$ & Diploma Thesis \\
\hline 17 & Equipment management & $\mathrm{N} / \mathrm{A}$ & Yes & \\
\hline 18 & Human behavior in emergencies & Yes & $\mathrm{N} / \mathrm{A}$ & \\
\hline
\end{tabular}

\section{The Same Pattern Shows in Themes and Categories}

By lumping codes into categories (Vaismoradi et al., 2013), the authors find two patterns that can be found in both curriculums: 1) knowledge related to the four phases of $\mathrm{EM}$, and 2) the policies and strategies to manage disasters. This finding demonstrates that firefighter educations in both countries put much emphasis on emergency management and the related policies. More specifically, by looking at the subjects of both firefighting educations (see Figure 1), preparing for and responding to disasters are two major responsibilities for firefighters in both countries. This fact echoes Chang and Neal's (2019) analysis of American firefighting and emergency management textbooks and historic documents.

\section{Differences Between Two Curriculums}

The Consideration of Human Behavior in Emergencies

As shown in Table 4, the CPAPFA does not have any courses focused on or related to human behavior during emergencies. According to the FESHE Model (National Fire Academy, 2019b, p.9), this course mainly presents the study of human behavior in fire and other emergencies, it combines knowledge in the areas of psychology and sociology, coupled with engineering and education to produce the best possible outcomes in terms of human survivability in an emergency. The benefit of introducing this kind of knowledge seems obvious, students would be able to understand human behaviors under extreme situations (e.g., fires and disasters), which means they could better prepare for and respond to emergencies. This kind of knowledge will also benefit emergency planning, training/drilling, and mass evacuation (O'Leary, 2004); both are core missions for fire departments in both countries. 


\section{Figure 1.}

Subjects classified by categories

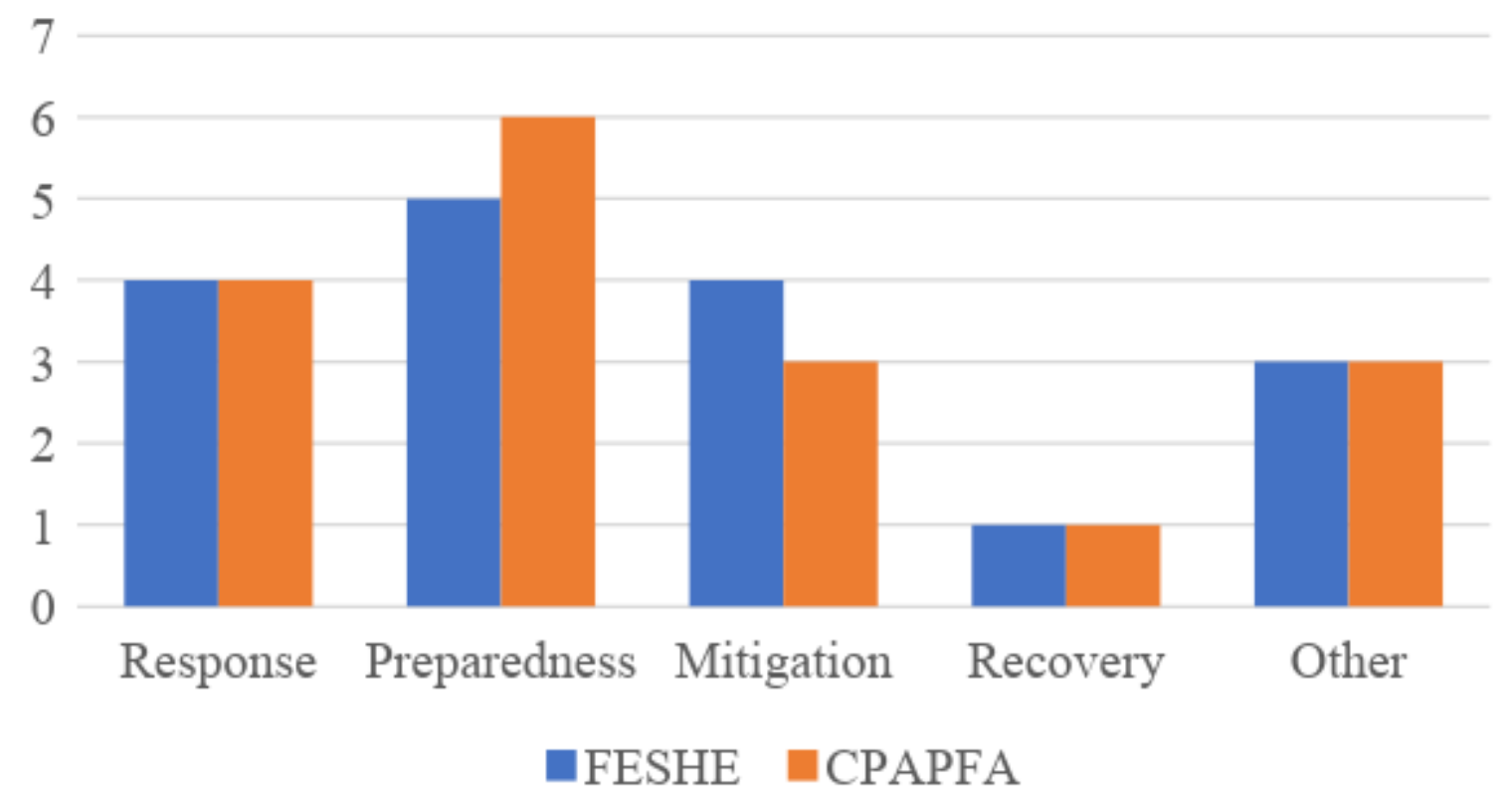

Although the CPAPFA does not provide human behavior classes as part of their curriculum, human behavior related research is an important topic for Chinese scholars. Chinese researchers realize human behaviors determine how we respond to disasters, and thus, can reduce the fatalities during emergencies. Consequently, people incorporate and consider human factors (e.g., human behaviors) when they design buildings and disaster drills (Zhang \& Chen, 2001; Wen \& Chen, 1999; Zhang \& Shi, 2005; Zhou, 2011). The absence of human behavior related courses indicates that the CPAPFA focuses too much on how responders perform on the sites (e.g., skills and techniques used to complete the search and rescue activities), but not how citizens react to disastrous situations. As Auf der Heide and Scanlon (2007) mention, it is more effective to find out how people normally respond to an alarm and then base an emergency plan on that, than to design a plan and expect people to follow it. Both researchers believe adding courses related to human behaviors are imperative for the Chinese firefighting higher education programs.

\section{The Approach to Cultivate the Research Ability is Different}

As mentioned in this paper, code 18, Fire Research Ability, only shows itself in the FESHE Model. Although Chinese students do not take this class, they are required to defend a research project before they earn a bachelor's degree. Consequently, it is rational to assume both countries want their fire graduates to have research skills and be able to complete research projects. In the FESHE Model, students are presented with a systematic and thorough introduction concerning how to conduct a research project. Whereas in CPAPFA, students acquire this ability during the time when they write their final research reports with their academic advisers. The American fire education system focuses on building theoretical frameworks, but it lacks the ability to provide hands-on experience for its graduates. This is probably due to American fire educators and trainers distinguish training and education 
programs clearly and thus all hands-on courses would be provided during training. Chinese students, on the contrary, have opportunities to complete a research project, but they do not have the opportunity to take research classes. As a result, the authors believe both countries can learn from each other. Taking research classes and then completing research projects would help fire students develop a broader view of firefighting training and work, and thus benefit their future careers.

\section{Different Emphases on Firefighting Education}

By comparing both the core and non-core courses (see Table 5) the authors find that FESHE and CPAPFA have some different approaches to the subjects that should be considered as "core". According to The Glossary of Education Reform, a core course of study, "refers to a series or selection of courses that all students are required to complete before they can move on to the next level in their education or earn a diploma" (Glossary of Education Reform, 2015). The general educational purpose of a core course of study is to ensure that all students take and complete courses that are considered to be academically and culturally essential-i.e., courses that teach students the foundational knowledge and skills they will need in college, their careers, and as adults. The core courses in the curriculum should reflect the educator's assessment about the important courses or KSA/KSAs which students need to learn from their education.

As a result, the researchers utilized the Codebook (see Appendix) to analyze the curriculums from U.S. and China. By analyzing the distribution of the core subjects in different curriculums, the authors find that although the educational content of the two curriculums is approximately the same as discussed earlier in this paper, the emphasis is very different.

As shown in Table 4, there are two courses considered core in both FESHE and CPAPFA, which are Organizational Management and Research Ability. The reason might be that both educational systems believe that after graduation, students will be managers in fire services, so it is important for them to understand how to conduct basic research related to emergency management or fire, either in the context of higher education or job requirements.

As to the differences shown in Table 4, FESHE focuses more on the EM strategies on pre-disaster phases, including Risk Reduction and Fire Organization Management. Whereas CPAPFA emphasizes heavily on the ability to handle the work efficiently during the phase of response, it also recognizes training, equipment management, and fire-related theories as core, which could be interpreted as the effort to maintain or enhance the ability to effectively respond to different emergencies. The reason of this could also be traced to the differences in their fire service systems. Chinese students from CPAPFA are supposed to be a qualified fire officer and fire commander. In the U. S., students are supposed to do a variety of work related to emergency management. The training or education needed for people to become an Incident Commander or firefighter is provided as different training programs, such as Executive Fire Officer (EFO) Program, according to NFA's introduction, which provides senior fire officers with a broad perspective on various facets of fire and emergency services administration.

Such differences in curriculum design also correspond to the different educational expectations in the two countries.

In China, fire service is part of its national defense system. Every student in CPAPFA is sponsored by the nation, and after graduation students would be qualified to serve as fire officers in fire departments. The CPAPFA expects the student to be fully qualified to 
complete basic fire service assignments, such as the ability to direct firefighting operations, manage a fire service branch, and organize training activity. The purpose of education is clear, but the dilemma is clear as well: the designer of this curriculum wants to make sure that if the student is assigned to a position other than fire commander, he or she is still qualified.

Table 4.

\begin{tabular}{|c|c|c|c|c|}
\hline \multicolumn{5}{|c|}{ Core-subjects } \\
\hline No. & Core-subject & FESHE & CPAPFA & \\
\hline 1 & Command & Non-core & Core & \\
\hline 2 & Firefighting Operations & Non-core & Core & \\
\hline 3 & Hazardous material incident response & Non-core & Core & \\
\hline 4 & Equipment management & Non-core & Core & \\
\hline 5 & Risk reduction & Core & Non-core & \\
\hline 6 & Fire-related Theories & Non-core & Core & \\
\hline 7 & Law-related issues in fire service & Core & Non-core & \\
\hline 8 & Organizational Management & Core & Core & * \\
\hline 9 & Training & Non-core & Core & \\
\hline 10 & Research Ability & Core & & Diploma Thesis \\
\hline
\end{tabular}

American fire students have various career options after they graduate from firefighting higher education programs, thus their higher education is more like a preparation for possible firefighting related careers that provide fundamental knowledge for students to serve on firefighting and emergency management organizations. For those who choose to be firefighters, FEMA has set up an education model and expectations to guide them to be promoted from a firefighter to fire officers, and eventually to become a Fire Chief. Comparing to CPAPFA, the FESHE Model is more flexible and allows students to build up comprehensive understandings of fire science. The FESHE educational model also equips students with basic knowledge and skills needed to work at fire departments. Since Command related courses are not required in the U.S. firefighting higher education programs, when American firefighters look for managerial positions in fire departments, they need to take additional incident command related courses and training to become qualified incident commanders.

\section{Significance and Conclusion}

The importance of education in the fire service could never be over-exaggerated. Although different countries may have different fire service systems, the value of the fire service higher education in each country might not vary that much, and so is the educational content based on this research. By utilizing the methodology of content analysis, the authors make a systematic comparison between the fire service higher education in the U. S. and China. The findings of this research indicates that there is the potential to establish an international standard curriculum, and by defining the core and non-core courses based on their domestic fire and emergency management systems, different countries could customize the standardized curriculum as they need. This research is also of great importance for China's newly established National Ministry of Emergency Management, of which higher education is a key part.

The U.S. is the pioneer in promoting a standardized fire service higher education and is the model for many countries in their development of a national emergency management system. The experience and the practice in this process in the past three decades is something worthy of referring to other countries. By analyzing the commonness in two sample 
curriculums, the authors present the possibility to set up an international standardized curriculum model. By analyzing the differences, the authors make some suggestions for Chinese fire service higher education: to increase the knowledge of human behavior in emergencies, to increase the knowledge of recovery in responders' perspective, and to increase the knowledge of research theories.

Higher education in fire service should serve to prepare its members to successfully manage personnel and conduct the department's day-to-day operations. Perhaps both countries should take a closer look at the other's curriculum and see if there is something to learn in order to improve its own education system. Moreover, CPAPFA needs to do more research on foreign countries' fire service higher education systems and curriculums. After all, being the only institute providing such an education in China, it is hard to see the shortcomings of its own system for the lack of outside competition. In addition, it should design more courses based on human relations and management, for firefighting involves more than just putting out fires

\section{References}

Alexander, D. (2003). Towards the development of standards in emergency management training and education. Disaster Prevention and Management: An International Journal, 12(2), 113-123. https://doi.org/10.1108/09653560310474223

An, T., Mintos, A., \& Yagit, M. (2013). A cross-national standards analysis: quadratic equations and functions. Eighth Congress of European Research in Mathematics Education (CERME 8), Manavgat-Side, Antalya - Turkey.

Andrews, P., Sayers, J., \& Marschall, G. (2015). Developing foundational number sense: Number line examples from Poland and Russia. Ninth Congress of European Research in Mathematics Education (CERME 9), Prague, Czech Republic.

Angle, J. S., Gala, M. F., Harlow, D., \& Lombardo, W. (2013). Firefighting strategies and tactics (3rd Edition). Jones \& Bartlett Learning.

Ary, D., Jacobs, L.C., Sorensen, C. K., \& Razavieh A. (2010). Introduction to research in education ( $8^{\text {th }}$ Edition). Cengage Learning.

Auf der Heide, E., \& Scanlon J. (2007). The role of the health sector in planning and response. In W. Waugh and K. Tierney (Eds.), Emergency management: Principles and practice for local government (2 ${ }^{\text {nd }}$ Edition), (pp. 107-123). ICMA Press.

Baird, M. E. (2010). The "phases" of emergency management. Intermodal Freight Transportation Institute (IFTI), University of Memphis. https://www.memphis.edu/ifti/pdfs/cait phases of emergency mngt.pdf

Blanchard, B. W. (2004). FEMA higher education project. FEMA Higher Education Workshop. Emmitsburg, MD. https://training.fema.gov/hiedu/docs/crpt.doc

Bockenstedt, G. (1997, December). Public safety. Governing, p. 9

Bofah, E. A., \& Hannula, M. (2011). The case of calculus: Comparative look at task representation in textbooks. Seventh Congress of European Research in Mathematics Education (CERME 7), Rzeszów, Poland.

Broman, J. (2008). The importance of higher education in the fire service. Fire Rescue Magazine. https://www.firefighternation.com/firerescue/the-importance-of-highereducation-in-the-fire-service/\#gref

Brown, R. G. (2009). Policy change, graphing calculators and 'High stakes examinations': A view across three examination systems. Sixth Congress of European Research in Mathematics Education (CERME 6), Lyons, France.

Chang, H. (2007, November). EMS: A comparison netween Taiwan and the United States. 
Fire Engineering Magazine, 11(160), 111-117.

Chang, R. H., \& Neal, D. (2019). Promotion or transition: From fire officer to emergency manager. Journal of Emergency Management, $17(2), 101$.

https://doi.org/10.5055/jem.2019.0402

Clark, B. A. (1993). Higher Education and Fire Service Professionalism. Fire Chief, 50-53.

Clarke, D., \& Xu, L. H. (2009). Spoken mathematics as a distinguishing characteristic of mathematics classrooms in different countries. Sixth Congress of European Research in Mathematics Education (CERME 6), Lyons, France.

Collier, D. (1991). The comparative method: Two decades of change. in D. Rustow and K. Erickson (Eds.), Comparative political dynamics: Global research perspectives (pp. 7-31). HarperCollins.

Downe-Wamboldt, B. (1992). Content analysis: Method, applications, and issues. Health Care for Women International, 13(3), 313-321.

https://doi.org/10.1080/07399339209516006

Drabek, T. E. (2003). Strategies for coordinating disaster responses. University of Colorado Institute of Behavior.

Dynes, R. R. (1988). Cross-cultural international research: Sociology and disaster. International Journal of Mass Emergencies and Disasters, 6(2), 101-129.

Etikan, I., Musa, S.A., \& Alkassim, R.S. (2016). Comparison of convenience sampling and purposive sampling. American Journal of Theoretical and Applied Statistics, 5(1), 1-4. https://doi.org/10.11648/j.ajtas.20160501.11

Field, P. A., \& Morse, J. M. (1985). Nursing research: The application of qualitative approaches. Croom Helm.

Freidson, E. (2001). Professionalism, the third logic: On the practice of knowledge. University of Chicago Press.

Geertz, C. (1973). Thick description: Toward an interpretive theory of culture. In The Interpretation of cultures: Selected essays (pp. 3-30). Basic Books.

Glossary of Education Reform. (2015, August 12). Curriculum Defintion. https://www.edglossary.org/curriculum

Goedegebuure, L., \& Van Vught, F. (1996). Comparative higher education studies: The perspective from the policy sciences. Higher Education, 32(4), 371-394. https://doi.org/10.1007/bfo0133253

Gosztonyi, K. (2015). The 'new math' reform and pedagogical flows in Hungarian and French mathematics education. Ninth Congress of European Research in Mathematics Education (CERME 9), Prague, Czech Republic.

Jahn, D. (2010). What is comparative politics? Standpoints and debates in Germany and the United States. Zeitschrift Für Vergleichende Politikwissenschaft, 4, 17-34. https://doi.org/10.1007/s12286-010-0080-Z

Kreps, G. A. (1991). Organizing for emergency management. In T. S. Drabek \& G. J. Hoetmer (Eds.), Emergency management: Principles and practice for local government $\left(2^{\text {nd }}\right.$ Edition) (pp. 30-54). ICMA Press.

Landman, T. (2003). Issues and methods in comparative politics. An introduction (2nd ed.). Routledge.

Latin, O. (1992). Command staff executives need a college degree (Unpublished manuscript). National Fire Academy.

Leath, E. M. (2007, April 1). Higher Education = Better Skills, Better Future. Fire Engineering. https://www.fireengineering.com/firefighting/higher-education- 
better-skills-better-future/\#gref

Lindell, M. K., Perry, R. W., Prater C. S., \& Nicholson, W. C. (2006). Fundamentals of emergency management. Federal Emergency Management Agency.

Marcino D., \& Gordon K. (2018). An overview of the National Microbiology Laboratory emergency management program. Canada Communicable Disease Report, 44(5), 102105. https://doi.org/10.14745/ccdr.v44i05a02

McEntire, D. A. (1997). Reflecting on the weaknesses of the international community during the IDNDR: Some implications for research and its application. Disaster Prevention and Management, 6(4), 221-233. https://doi.org/10.1108/09653569710179066

McEntire, D. A., \& Mathis, S. (2007). Comparative politics and disasters: assessing substantive and methodological contributions. In: D. A. McEntire (Ed.), Disciplines, disasters and emergency management: The convergence and divergence of concepts, issues and trends from the research literature (pp. 178-195). Charles C. Thomas Publisher.

Moschella, J. M. (2004). Fire service higher education in the U.S. and Taiwan: A comparison. Fire Engineering, 157(11), 105-112.

Mourchid, Y. (2006, May 31). The fire service and higher education: Occupation vs. profession. Firehouse. https://www.firehouse.com/home/article/10501102/the-fireservice-and-higher-education-occupation-vs-profession.

National Fire Academy. (2019a). National Fire Academy FESHE model curriculum bachelor's (core). Federal Emergency Management Agency. https://www.usfa.fema.gov/downloads/pdf/nfa/higher_ed/bachelor_curriculum_c ore.pdf

National Fire Academy. (2019b). National Fire Academy FESHE model curriculum bachelor's (non-core). Federal Emergency Management Agency. https://www.usfa.fema.gov/downloads/pdf/nfa/higher ed/bachelor curriculum n oncore.pdf

National Research Council. (2004). On evaluating curricular effectiveness: Judging the quality of K-12 mathematics evaluations. The National Academies Press. https://doi.org/10.17226/11025

O’Neal, D. B. (1997, November). But what about an ALS plow unit. Florida Fire Service Today, 11.

O’Neal D. B. (1998). The impact of academic achievement and professional certification on Florida fire service efficiency. National Fire Academy.

O'Leary M. R. (2004). The first 72 hours: A community approach to disaster preparedness. iUniverse.

Paisey, C. and Paisey, N. J. (2010) Comparative research: An opportunity for accounting researchers to learn from other professions. Journal of Accounting E Organizational Change, 6(2), 180-199. https://doi.org/10.1108/18325911011048754

Palys, T. (2008). Purposive sampling. In L. M. Given (Ed.), The Sage Encyclopedia of Qualitative Research Methods (Vol. 2) (pp. 697-698). Sage.

Patton, M. Q. (2002). Qualitative research and evaluation methods (3rd ed.). Sage.

Peacock, W. (1997). Cross-national and comparative disaster research. International Journal of Mass Emergencies and Disasters, 15(1), 117-133.

Ponte, J. P. and Marques, S. (2007). Proportion in school mathematics textbooks: A comparative study. Sixth Congress of European Research in Mathematics Education (CERME 6), Lyons, France. 
Richmond, W. C. (1998, April). Paving the path to advancement. Fire Station Management Advisor, 6.

Sartori, G. (1991). Comparing and miscomparing. Journal of Theoretical Politics, 3(3), 243-257. https://doi.org/10.1177/0951692891003003001

Sinha, D. K. (1992). Natural disaster reduction for the nineties: Perspectives, aspects and strategies. International Journal Services.

Snodgrass, P. (2011). Peers are driving force for national fire curriculum. Firehouse. https://www.firehouse.com/home/article/10313714/higher-education-for-the-fireservice.

Teichler, U. (2014). Opportunities and problems of comparative higher education research: The daily life of research. Higher Education, 67(4), pp. 393-408. http://www.jstor.org/stable/43648663.

U.S. Fire Administration. (2019a). Fiscal year 2018 report to congress. Federal Emergency Management Agency. https://www.usfa.fema.gov/downloads/pdf/annual report fy 18.pdf.

U.S. Fire Administration. (2019b). Fire and Emergency Services Higher Education model course outlines. Federal Emergency Management Agency. https://www.usfa.fema.gov/training/prodev/model courses.html

Vaismoradi, M., Turunen, H., \& Bondas, T. (2013). Content analysis and thematic analysis: Implications for conducting a qualitative descriptive study. Nursing $\mathcal{E}^{2}$ Health Sciences, 15(3), 398-405. https://doi.org/10.1111/nhs.12048

Van de Vijver, F., \& Leung, K. (1997). Methods and data analysis for cross-cultural research. Sage.

Wang Z., Chan E. Y. Y., Liu, C. K., \& Yeung, M. P. S. (2016). The disaster and emergency management cystem in China. Collaborating Centre for Oxford University and CUHK for Disaster and Medical Humanitarian Response. http://ccouc.org/_asset/file/policybrief-disaster-andemergmxsysinchinafinal20161020.pdf

Wen, L. M., \& Chen, B. Z. (1999). Study on the human evacuation behavior export system while fire. Journal of Northeastern University (Natural Science), 20(1), 34-37.

Witt, J. L. (1996). Message from the Director. Emergency Management Institute 1996-1997 Catalog of Activities, p. 3.

Yi, L., Ge, L., Zhao, D., Zhou, J., \& Gao, Z. (2011). An analysis on disasters management system in China. Natural Hazards, 60(2), 295-309. https://doi.org/10.1007/s11069011-0011-6

Zhang, P. and Chen, B. (2001). Behavior rules of human evacuation in fire. Journal of Northeastern University, 22, 55-56.

Zhang, S. and Shi X. (2005). Study on human and fire in building. Fire Science and Technology. 24(2), 178-181.

Zhou, J. (2011). Research on planning support methodology for urban fire protection planning. (Doctoral Dissertation, Wuhan University). 


\begin{abstract}
About the Authors
Yunbo Zhang is a lecturer in the Department of Fire Commanding at China People's Police University (CPPU). He earned his master's degree in Military Science at the Chinese People's Armed Police Force Academy. He previously directed the bachelor degree program accreditation at CPPU, and worked with Dr. Ray Chang in Oklahoma State University's Fire Administration and Emergency Management Program as a visiting scholar. He intends to deepen his research in this field to benefit the emergency management educational institutions in China, and support those establishing new emergency management systems.

Ray Hsienho Chang, Ph.D., is an assistant professor in Embry-Riddle Aeronautical University-Worldwide, USA. He has published several research articles relevant to disaster response and disaster preparedness. He earned his Ph.D. in Disaster Management and his master's degree in Fire Service Administration. Before he pursued a doctoral degree, he served as a fire officer in Taiwan for six years. By combining his educational training with his practical background, Dr. Chang hopes to bridge the gap between academics and practitioners, and believes his Asian heritage and cross-cultural training will benefit disaster management systems around the world.

Dengyou Xia, Ph.D., is a professor in the Department of Fire Commanding at China People's Police University (CPPU). He is also the director of the bachelor degree program in Fire Office Commanding and the manager of Fire Commanding Teaching and Researching at CPPU. He earned his Ph.D. in Safety Science and Engineering at the Beijing Institute of Technology. His research mainly focuses on emergency decision making and emergency management.
\end{abstract}




\section{Appendix:}

The Codebook

\begin{tabular}{|c|c|c|c|}
\hline Theme & Categories & Codes & Description \\
\hline \multirow{12}{*}{$\begin{array}{l}\text { Knowledge } \\
\text { about } \\
\text { Emergency } \\
\text { Management }\end{array}$} & \multirow{4}{*}{ Response } & Command & $\begin{array}{l}\text { To conduct on-scene management and control } \\
\text { reasonably. }\end{array}$ \\
\hline & & $\begin{array}{l}\text { Disaster } \\
\text { Response }\end{array}$ & $\begin{array}{l}\text { To prepare for potential disasters and provide } \\
\text { immediate assistance to maintain life, improve health } \\
\text { and support the morale of the affected population, after } \\
\text { a disaster occurs. }\end{array}$ \\
\hline & & $\begin{array}{l}\text { Firefighting } \\
\text { Operations }\end{array}$ & $\begin{array}{l}\text { To fulfill the task of saving lives, stabilizing the } \\
\text { incident and conserving property. }\end{array}$ \\
\hline & & $\begin{array}{l}\text { Hazardous } \\
\text { Material } \\
\text { Incident } \\
\text { Response }\end{array}$ & Managing hazardous materials emergencies \\
\hline & \multirow{5}{*}{ Preparedness } & $\begin{array}{l}\text { Emergency } \\
\text { planning }\end{array}$ & $\begin{array}{l}\text { To prepare for the chances of emergencies that might } \\
\text { occur, to reduce their impact on residents and the } \\
\text { environment to a minimum. }\end{array}$ \\
\hline & & $\begin{array}{l}\text { Hazardous } \\
\text { material incident } \\
\text { preparedness }\end{array}$ & $\begin{array}{l}\text { Preparing for and managing hazardous materials } \\
\text { emergencies. }\end{array}$ \\
\hline & & $\begin{array}{l}\text { Equipment } \\
\text { management }\end{array}$ & $\begin{array}{l}\text { Basic knowledge about the kinds of equipment that are } \\
\text { commonly used by fire departments, and how to } \\
\text { manage them as a fire officer. }\end{array}$ \\
\hline & & Leadership & $\begin{array}{l}\text { To handle the managerial issues legally and ethically } \\
\text { as a qualified leader, including the knowledge of } \\
\text { personnel management, training and administration of } \\
\text { a fire service entity. }\end{array}$ \\
\hline & & Training & $\begin{array}{l}\text { Knowledge of how to lead, instruct or organize the } \\
\text { training programs. }\end{array}$ \\
\hline & \multirow{2}{*}{ Mitigation } & Risk reduction & $\begin{array}{l}\text { To reduce the emergency risk in a community legally } \\
\text { and ethically. }\end{array}$ \\
\hline & & $\begin{array}{l}\text { Fire } \\
\text { investigation }\end{array}$ & $\begin{array}{l}\text { How to collect, analyze, and report detailed fire } \\
\text { experience data through on-site investigations. }\end{array}$ \\
\hline & Recovery & Recovery & The process of returning a community to "normal." \\
\hline \multirow{6}{*}{$\begin{array}{l}\text { Firefighting } \\
\text { related } \\
\text { knowledge }\end{array}$} & \multirow{3}{*}{$\begin{array}{l}\text { Technologies and } \\
\text { theories related to } \\
\text { emergency } \\
\text { management }\end{array}$} & $\begin{array}{l}\text { Human behavior } \\
\text { in emergencies }\end{array}$ & $\begin{array}{l}\text { To understand normally how human behavior changes } \\
\text { in fire and other emergencies, combined with } \\
\text { psychology and sociology. }\end{array}$ \\
\hline & & $\begin{array}{l}\text { Structural fire } \\
\text { protection } \\
\text { systems }\end{array}$ & $\begin{array}{l}\text { The underlying principles involved in structural fire } \\
\text { protection systems, and how to utilize these systems to } \\
\text { reduce fire risk or put out the fire. Including Chemical } \\
\text { Safety Technologies such as the basic knowledge } \\
\text { about chemical safety and technologies commonly } \\
\text { adopted in this industry. }\end{array}$ \\
\hline & & $\begin{array}{l}\text { Fire-related } \\
\text { Theories }\end{array}$ & $\begin{array}{l}\text { Basic theories about fire-related subjects, which will } \\
\text { help the student to better understand technologies and } \\
\text { skills related to fire service, such as ventilation, fire } \\
\text { dynamics, and hydromechanics. }\end{array}$ \\
\hline & \multirow{2}{*}{ Law and ethics } & $\begin{array}{l}\text { Law-related } \\
\text { issues in fire } \\
\text { service }\end{array}$ & $\begin{array}{l}\text { About national legal system and legal issues involving } \\
\text { administrative, operational matters, law enforcement } \\
\text { with regard to the fire service. }\end{array}$ \\
\hline & & $\begin{array}{l}\text { Ethical issues in } \\
\text { fire service }\end{array}$ & $\begin{array}{l}\text { Ethical issues involving in fire service, including } \\
\text { organizational administrative issues and law } \\
\text { enforcement. }\end{array}$ \\
\hline & Research ability & Research ability & How to conduct fire related research. \\
\hline
\end{tabular}

